\title{
Spatial variability and temporal trends in water-use efficiency of European forests
}

Running head: Water-use efficiency trends in Europe

Matthias Saurer ${ }^{1}$, Renato Spahni ${ }^{2,4}$, David C. Frank ${ }^{3,4}$, Fortunat Joos ${ }^{2,4}$, Markus Leuenberger ${ }^{2}$, Neil J. Loader ${ }^{5}$, Danny McCarroll ${ }^{5}$, Mary Gagen ${ }^{5}$, Ben Poulter ${ }^{6}$, Rolf T.W. Siegwolf ${ }^{1}$, Laia Andreu-Hayles $^{7}$, Tatjana Boettger ${ }^{8}$, Isabel Dorado Liñán ${ }^{9,}$ 10, Ian J. Fairchild ${ }^{11}$, Michael Friedrich $^{12}$, Emilia Gutierrez ${ }^{9}$, Marika Haupt ${ }^{8}$, Emmi Hilasvuori $^{13,}{ }^{14}$, Ingo Heinrich ${ }^{15}$, Gerd Helle $^{15}$, Håkan Grudd ${ }^{16}$, Risto Jalkanen ${ }^{17}$, Tom Levanič ${ }^{18}$, Hans W. Linderholm ${ }^{19}$, Iain Robertson $^{5}$, Eloni Sonninen ${ }^{13}$, Kerstin Treydte ${ }^{3}$, John S. Waterhouse ${ }^{20}$, Ewan J. Woodley ${ }^{5,21}$, Peter M. Wynn ${ }^{22}$, Giles H.F. Young ${ }^{5}$

${ }^{1}$ Paul Scherrer Institut, Villigen, Switzerland

${ }^{2}$ University of Bern, Bern, Switzerland

${ }^{3}$ Swiss Federal Research Institute WSL, Birmensdorf, Switzerland

${ }^{4}$ Oeschger Centre for Climate Change Research, University of Bern, Bern,

Switzerland

${ }^{5}$ Department of Geography, Swansea University, Swansea, UK

${ }^{6}$ Laboratoire des Sciences du Climat et de L'Environment, Gif-sur Yvette, France

${ }^{7}$ Tree-Ring Laboratory, Lamont-Doherty Earth Observatory of Columbia University, Palisades, NY 10964, USA

${ }^{8}$ Department of Catchment Hydrology, Helmholtz Centre for Environmental Research - UFZ, Germany

${ }^{9}$ Dept d'Ecologia, Facultat de Biologia, Universitat de Barcelona, Barcelona, Spain

${ }^{10}$ Chair of Ecoclimatology, Technische Universität München, Freising, Germany

${ }^{11}$ School of Geography, Earth \& Environmental Sciences, University of Birmingham, B15 2TT, UK

${ }^{12}$ Institute of Botany, Hohenheim University, Stuttgart, Germany 
${ }^{13}$ Laboratory of Chronology, Finnish Museum of Natural History, P.O.Box 64, 00014 University of Helsinki, Helsinki, Finland

${ }^{14}$ Finnish Environment Institute, P.O.Box 140, 00251 Helsinki, Finland

${ }^{15}$ GFZ German Centre for GeoSciences, Climate Dynamics and Landscape Evolution, 14473 Potsdam, Germany

${ }^{16}$ Bolin Centre for Climate Research, Department of Physical Geography and Quaternary Geology, Stockholm University, Stockholm, Sweden

${ }^{17}$ Finnish Forest Research Institute, Northern Regional Unit, Rovaniemi, Finland

${ }^{18}$ Department of Yield and Silviculture, Slovenian Forestry Institute, Večna pot 2, 1000 Ljubljana, Slovenia

${ }^{19}$ University of Gothenburg, Gothenburg, Sweden

${ }^{20}$ Department of Life Sciences, Anglia Ruskin University, East Road, Cambridge CB1 1PT, UK

${ }^{21}$ Geography, College of Life and Environmental Sciences, University of Exeter, Rennes Drive, Exeter, EX4 4RJ, UK

${ }^{22}$ Lancaster Environment Centre, University of Lancaster, LA1 4YQ, UK

Accepted by Global Change Biology

Corresponding author: Matthias Saurer, matthias.saurer@psi.ch, Tel 0041563102749

\section{Keywords}

Tree rings, carbon isotope discrimination, climate change, dynamic vegetation model

\section{Type of paper}

Primary research article 


\begin{abstract}
The increasing carbon dioxide $\left(\mathrm{CO}_{2}\right)$ concentration in the atmosphere in combination with climatic changes throughout the last century are likely to have had a profound effect on the physiology of trees: altering the carbon and water fluxes passing through the stomatal pores. However, the magnitude and spatial patterns of such changes in natural forests remain highly uncertain. Here, stable carbon isotope ratios from a network of 35 tree-ring sites located across Europe are investigated to determine the intrinsic water-use efficiency (iWUE), the ratio of photosynthesis to stomatal conductance from 1901-2000. The results were compared with simulations of a dynamic vegetation model (LPX-Bern 1.0) that integrates numerous ecosystem and land-atmosphere exchange processes in a theoretical framework. The spatial pattern of tree-ring derived iWUE of the investigated coniferous and deciduous species and the model results agreed significantly with a clear south-to-north gradient, as well as a general increase in iWUE over the $20^{\text {th }}$ century. The magnitude of the iWUE increase was not spatially uniform, with the strongest increase observed and modelled for temperate forests in Central Europe, a region where summer soil-water availability decreased over the last century. We were able to demonstrate that the combined effects of increasing $\mathrm{CO}_{2}$ and climate change leading to soil drying have resulted in an accelerated increase of iWUE. These findings will help to reduce uncertainties in the land surface schemes of global climate models, where vegetation-climate feedbacks are currently still poorly constrained by observational data.
\end{abstract}




\section{Introduction}

Interactions among direct $\mathrm{CO}_{2}$ (fertilization) effects on plants and climatic conditions such as drought are of particular interest for understanding past and for predicting future forest growth and carbon sequestration. The continually increasing atmospheric $\mathrm{CO}_{2}$ concentration and concurrent climatic change are both likely to strongly affect the physiology of forests ecosystems and alter productivity, species distribution and vegetation-climate feedbacks. Yet, both the magnitude and mechanisms of forest response are unclear and furthermore are expected to be spatially very heterogeneous, depending at least upon both the local growth limitations (Babst et al., 2013) and the trajectory of future climate (IPCC, 2013). For many regions, ecosystem transitions are already underway (Allen et al., 2010, Parmesan \& Yohe, 2003). The effects of climate change and increasing $\mathrm{CO}_{2}$ concentrations could stimulate tree growth in some regions via enhanced photosynthesis through $\mathrm{CO}_{2}$ fertilization (Ainsworth \& Long, 2005). However, adverse effects from an increase in drought severity, for example, could result in reduced growth and increased stress and mortality (Zhao \& Running, 2010). Such changes will inevitably also modify biospheric $\mathrm{CO}_{2}$ and water fluxes and the relationships between them (Keenan et al., 2013, Schimel et al., 2001).

The slow adaption of late-successional forests, however, is difficult to assess either by observations or by experiments. Therefore it is not well known how the physiology of natural forests has already changed due to the increase of atmospheric $\mathrm{CO}_{2}$ concentration in the ca. 150 years since major global industrialisation. Increases in net ecosystem productivity inferred from small-scale $\mathrm{CO}_{2}$ fumigation or depletion experiments may overestimate the $\mathrm{CO}_{2}$-response in natural forests (Norby et al., 2010). Down-regulation of photosynthesis under elevated $\mathrm{CO}_{2}$ was observed and also the reduction in transpiration was found to be relatively small in a mature mixed deciduous forest (Leuzinger \& Körner, 2007). Accurate quantification of changes in water and $\mathrm{CO}_{2}$ fluxes over the last century, which are spatially 
highly variable, would be important because of their relationship with the carbon sequestration potential of the forests (Pan et al., 2011, Schimel et al., 2001), and evaporationtemperature feedbacks, i.e. possibly additional or reduced warming due to changes in evapotranspiration (Betts et al., 1997).

Stable carbon isotope ratios $\left(\delta^{13} \mathrm{C}\right)$ of tree-rings represent a valuable tool to improve understanding of forest response to the combined influence of climate and $\mathrm{CO}_{2}$ over time (McCarroll \& Loader, 2004). $\delta^{13} \mathrm{C}$ in plant organic matter is related to the ratio of net photosynthesis (A) to stomatal conductance to water (g), which is the intrinsic water-use efficiency $(\mathrm{iWUE}=\mathrm{A} / \mathrm{g}$ ), and therefore provides a measure for the relative water loss per molecule carbon acquired at the leaf level (Farquhar et al., 1982). Plant water-use efficiency (WUE) defined as the ratio of carbon uptake to actual water loss at the plant level is an essential element of the survival and productivity of plants. Actual WUE depends on the evaporative demand, as transpiration is determined by the product of stomatal conductance and vapour pressure deficit, while iWUE may be considered as a potential WUE and does not consider this variable environmental constraint and respiratory losses (Seibt et al., 2008). This limitation of the isotope approach may be overcome by using plant physiological models to assist data interpretation. For assessments that strive to consider both spatial and temporal variability in plant-climatic- $\mathrm{CO}_{2}$ interactions, a dynamic vegetation model such as the LundPotsdam-Jena (LPJ) model that combines process-based vegetation dynamics with landatmosphere carbon and water exchange is particularly useful (Sitch et al., 2003). Such models have been widely applied to study the influence of increasing $\mathrm{CO}_{2}$ on net primary productivity changes (Hickler et al., 2008). Few studies have discussed possible changes in WUE under variable climate and $\mathrm{CO}_{2}$ concentrations, and those that do generally find increasing WUE over time (De Kauwe et al., 2013, Tian et al., 2010); however, no long-term verification of 
model results with carbon isotope data of tree-rings has been carried out. The uncertainty of this forest-climate feedback is therefore very high.

Previous tree-ring carbon isotope studies have identified an increase in iWUE over the $20^{\text {th }}$ century at most forest sites so far investigated across the globe, including sites from the tropics (Hietz et al., 2005, Loader et al., 2011), northern high- and mid-latitudes (Gagen et al., 2011, Saurer et al., 2004, Waterhouse et al., 2004) and the Mediterranean basin (AndreuHayles et al., 2011, Linares et al., 2009), but to varying degrees. Some studies indicated a passive response of the plants to increasing atmospheric $\mathrm{CO}_{2}$ concentration $\left(c_{a}\right)$, where the intercellular $\mathrm{CO}_{2}$ concentration $\left(\mathrm{c}_{\mathrm{i}}\right)$ increased by the same amount as $\mathrm{c}_{\mathrm{a}}$ (implying $\mathrm{c}_{\mathrm{a}}-\mathrm{c}_{\mathrm{i}}=$ constant), which resulted in no iWUE improvement (Marshall \& Monserud, 1996). However, more commonly an active response was observed, where $c_{i}$ increased more slowly than $c_{a}$ due to plant adaptation, resulting in higher iWUE (Feng, 1998). Several studies have reported that the response to increasing $\mathrm{CO}_{2}$ concentrations changed from being active $\left(\mathrm{c}_{\mathrm{i}} / \mathrm{c}_{\mathrm{a}}\right.$ constant) to passive ( $\mathrm{c}_{\mathrm{a}}-\mathrm{c}_{\mathrm{i}}$ constant) around the 1970s (Gagen et al., 2011, Waterhouse et al., 2004) with an approximate levelling of iWUE, or even a decrease in polluted areas (Boettger et al., 2014). No clear spatial pattern of the iWUE increase has emerged from the published literature, partly due to the unsystematic and still sparse nature of the data collection.

In this investigation, we employ a network of tree-ring sites across Europe to study the spatial and temporal patterns in the carbon to water-use relationships. Thirty-five old-growth forest sites are investigated that cover a large climatic gradient from Mediterranean Southern Europe to the tree line Northern Fennoscandia, including both coniferous and deciduous species from five genera (Abies, Larix, Pinus, Picea, Quercus). The $\delta^{13}$ C-derived changes in iWUE over the $20^{\text {th }}$ century are investigated as a function of the climate change at each location (temperature, precipitation, soil water content). The empirical data are compared to iWUE 
derived from a dynamic vegetation model, enabling a detailed assessment of functional relationships between physiology and climate for the entire European domain. 


\section{Materials and Methods}

Sampling and isotope analysis

A network of 35 tree-ring sites across Europe was established within the two EU-funded projects ISONET (20 sites; Treydte et al. 2007) and Millennium (15 additional sites, Table 1). The sampling design considered temperate sites, where tree-growth is governed by a mixture of environmental factors, as well as ecologically extreme sites near the tree-line, where a single climatic factor dominates tree growth (Treydte et al., 2007) (Table S1). The altitude range of study sites is from 5-2200 m, with the majority situated in two elevation bands: 0$500 \mathrm{~m}$ and 1500-2200 m. High-altitude sites are concentrated towards the south of the study region. We focused on oak as an important deciduous species together with various coniferous species, selecting the most abundant and long-lived trees at each location. At least four trees were sampled at all sites (usually 2 cores per tree), sufficient to develop an isotope site record representative of the population (Leavitt \& Long, 1984). In general, whole rings (early- and latewood) were analyzed for the conifers, whereas for oaks, latewood was separated from earlywood because a significant proportion of the carbon incorporated in the earlywood is carried over in deciduous species from carbohydrate reserves established in the previous year (Treydte et al., 2007). Tree-ring samples were cross-dated to ensure the correct calendar year was assigned to each annual ring, and then individual rings separated with a razor-blade under a microscope. At some sites, tree-rings from the same year were pooled prior to cellulose extraction, while at others individual trees were measured, but all analysis here is based on average site chronologies. Cellulose was extracted using standard techniques (Boettger et al., 2007). Carbon isotope analysis was conducted on $\mathrm{CO}_{2}$ obtained from combustion of the samples in an elemental-analyser and measurement in an isotope-ratio mass-spectrometer (McCarroll \& Loader, 2004). Isotope values are given as $\delta$-values

calculated from the isotope ratios ${ }^{13} \mathrm{C} /{ }^{12} \mathrm{C}(=\mathrm{R})$ as $\delta^{13} \mathrm{C}=\left(\mathrm{R}_{\text {sample }} / \mathrm{R}_{\text {standard }}-1\right) * 1000 \%$ o 
(referring to the international standard VPDB), and have a long-term estimated methodological error of $<0.2 \%$ (Boettger et al., 2007). Most analyses were performed on the common period from AD 1901 to AD 2000, although some records extend up to 2006.

\section{Data analysis}

The isotope discrimination $\Delta$ between plant material $\left(\delta^{13} \mathrm{C}_{\text {plant }}\right)$ and atmospheric $\mathrm{CO}_{2}\left(\delta^{13} \mathrm{C}_{\mathrm{atm}}\right)$ is defined as $\Delta=\left(\delta^{13} \mathrm{C}_{\mathrm{atm}}-\delta^{13} \mathrm{C}_{\mathrm{plant}}\right) /\left(1+\delta^{13} \mathrm{C}_{\mathrm{plant}} / 1000\right)$. According to Farquhar et al. (1982), $\Delta$ can be related to plant physiological properties approximately via the linear relationship $\Delta=$ $\mathrm{a}+(\mathrm{b}-\mathrm{a}) \mathrm{c}_{\mathrm{i}} / \mathrm{c}_{\mathrm{a}}$, where $\mathrm{a}$ is the fractionation associated with the diffusion of $\mathrm{CO}_{2}$ through the stomata $(\mathrm{a} \approx 4.4 \% \mathrm{o})$ and $\mathrm{b}$ is the fractionation resulting from enzymatic $\mathrm{C}$ fixation $(\mathrm{b} \approx 27 \% \mathrm{o})$. For the calculation of $\Delta$ for tree-rings, $\delta^{13} \mathrm{C}$-values of the atmosphere $\left(\delta^{13} \mathrm{C}_{\mathrm{atm}}\right)$ through time need to be estimated from ice-core data and recent atmospheric measurements (Leuenberger, 2007). Additionally, we corrected for the isotope offset between cellulose and total organic matter $\left(\delta^{13} C_{\text {plant-corrected }}=\delta^{13} C_{\text {plant cellulose }}-\right.$ offset $)$ because the leaf-level model for fractionation by Farquhar et al. (1982) is more representative for the bulk matter rather than a specific chemical compound such as cellulose. We used as offset the difference between cellulose and wood, which is $1.1 \% \pm \pm 0.2 \%$ for oak (Borella et al., 1998, Loader et al., 2003) and 1.3\% \pm 0.2\% for conifers (Saurer et al., 1997). This offset does, as a first approximation, consider different post-photosynthetic fractionations, including respiration, synthesis of secondary sugars, and fractionations during phloem loading and unloading (Gessler et al., 2009, Seibt et al., 2008). Based on the definition of the intrinsic water-use efficiency iWUE, the ratio of net photosynthesis $\mathrm{A}=\mathrm{g}_{\mathrm{CO} 2}\left(\mathrm{c}_{\mathrm{a}}-\mathrm{c}_{\mathrm{i}}\right)$ to conductance for water vapour $\mathrm{g}_{\mathrm{H} 2 \mathrm{O}}$, we obtain iWUE $=$ $\mathrm{A} / \mathrm{g}_{\mathrm{H} 2 \mathrm{O}}=\mathrm{g}_{\mathrm{CO} 2}\left(\mathrm{c}_{\mathrm{a}}-\mathrm{c}_{\mathrm{i}}\right) / \mathrm{g}_{\mathrm{H} 2 \mathrm{O}}=\left(\mathrm{c}_{\mathrm{a}}-\mathrm{c}_{\mathrm{i}}\right) / 1.6$, which can be calculated using $\mathrm{c}_{\mathrm{i}}$ from above (Ehleringer \& Cerling, 1995). Accordingly, the final equation for iWUE is: 
$i W U E=c_{a} \frac{b-\left[\frac{\delta^{13} C_{a t m}-\left(\delta^{13} C_{\text {cellulose }}-\text { offset }\right)}{1+\frac{\left(\delta^{13} C_{\text {cellulose }}-\text { offset }\right)}{1000}}\right]}{1.6(b-a)}$

The iWUE time series were investigated by high and low pass filtering using cubic smoothing splines with 50\% frequency response cut-off at 20 years (Cook \& Peters, 1981).

For climatological analysis, simulations and calculation of 1901-10 and 1991-2000 averages, we used the $0.5^{\circ} \times 0.5^{\circ}$ monthly gridded temperature and precipitation CRU TS 3.1 data for 1901-2006 (Mitchell \& Jones, 2005) and the Worldclim high-resolution dataset $\left(1 \mathrm{~km}^{2}\right)$ (Hijmans et al., 2005). Climatological analyses were also carried out with soil water content derived from the vegetation model (see below).

\section{Vegetation model}

For iWUE simulations we used the Land surface Processes and eXchanges (LPX-Bern 1.0) model (Spahni et al., 2013, Stocker et al., 2013), an improved version of the Lund-PotsdamJena (LPJ) global dynamic vegetation model (Gerber et al., 2003, Joos et al., 2004, Joos et al., 2001, Sitch et al., 2003, Stocker et al., 2011, Strassmann et al., 2008). Additionally to the standard LPJ version, the LPX-Bern (called LPX later in this paper) model includes special modules and features important for the iWUE calculation: updated soil and plant hydrology using leaf interception, surface evaporation, snow parameterisation and melting (Gerten et al., 2004, Murray et al., 2011, Wania et al., 2009), soil heat diffusion in eight soil layers regulating thawing and freezing in soil and related changes in the carbon pools (Wania et al., 2009), as well as dynamic interaction with the nitrogen cycle (Stocker et al., 2013, Xu-Ri \& Prentice, 2008, Xu-Ri et al., 2012). The model is forced by monthly temperature, precipitation and cloud cover from the CRU data (CRU TS 3.1, $0.5^{\circ}$ lat. x $0.5^{\circ}$ long.). The LPX uses a stochastic distribution of the monthly amount of precipitation for a prescribed number of rain 
days per month, as opposed to a constant amount of precipitation every day in LPJ (Sitch et al., 2003).

In LPX, the iWUE is calculated daily as the ratio of simulated net photosynthesis A to stomatal conductance $\mathrm{g}_{\mathrm{H} 2 \mathrm{O}}$ for average tree individuals at the ecosystem level. Photosynthetic assimilation of $\mathrm{CO}_{2}$ is modelled using a form of the Farquhar scheme (Farquhar et al., 1980) with leaf-level optimized nitrogen allocation (Haxeltine \& Prentice, 1996), and an empirical convective boundary layer parameterization to couple the carbon and water cycles (Gerten et $a l .$, 2004). The plant-available water is proportional to the soil water content in the top two metres and hydraulic constraints limiting tree height are not explicitly considered. Soils are subdivided in eight soil layers linked by percolation. Soil water content is fed by precipitation (after interception by vegetation canopy) and snow melt. Beside plant transpiration, water is also removed from the soil by direct soil evaporation, percolation and runoff (Gerten et al., 2004). Transpiration is described as a function of Potential Evapotranspiration and stomatal conductance $\left(\mathrm{g}_{\mathrm{H} 2 \mathrm{O}}\right)$, assuming water-saturated cell walls in the stomata. The $\mathrm{CO}_{2}$ flux from the atmosphere to the stomatal cavity is proportional to the $\mathrm{CO}_{2}$ difference between the atmosphere and the stomatal cavity $\left(\mathrm{c}_{\mathrm{a}}-\mathrm{c}_{\mathrm{i}}\right)$. Stomatal conductance for water, $\mathrm{g}_{\mathrm{H} 2 \mathrm{O}}$, and carbon dioxide, $\mathrm{g}_{\mathrm{CO} 2}$, are linearly related by their molecular diffusivities $\left(\mathrm{g}_{\mathrm{H} 2 \mathrm{O}} / \mathrm{g}_{\mathrm{CO} 2}=1.6\right)$. Stomatal conductance, and thus $c_{i}$, is varied to optimize assimilation for given environmental conditions, namely irradiance, temperature, water supply from soils, and $\mathrm{CO}_{2}$ concentration. This optimization is performed with the constraints that the $\mathrm{CO}_{2}$ assimilation equals the $\mathrm{CO}_{2}$ flux from the atmosphere into the stomatal cavity and that transpiration does not exceed water supply. In summary, assimilation, canopy conductance, and iWUE simulated by LPX depend in a non-linear and complex way on environmental conditions.

The plant functional types used in simulations of iWUE were 'temperate and boreal needle evergreen', 'temperate broadleaf summergreen' and 'boreal needle summergreen' in LPX, 
from here on referred to as conifers, oak and larch, respectively. Simulations were performed using dynamic fractional plant cover with competing plant functional types. The iWUE average was weighted by the fractional tree cover (per year and grid cell) and its net primary productivity (per month and $\mathrm{m}^{2}$ ). For the site-by-site evaluation, the tree-ring based iWUE was compared to the modelled grid cell average iWUE at the tree site. If the model did not simulate the growth of the expected tree type, the fractional tree-cover-weighted average of the eight neighbouring grid cells was used instead. The model results were further tested in sensitivity runs using constant atmospheric $\mathrm{CO}_{2}$, interactive nitrogen cycle (which used the deposition map by Lamarque et al. (2011), prescribed vegetation type, constant climate or were forced with a high-resolution climate data set interpolated to the tree site with corrected altitude. In simulations with an interactive $\mathrm{N}$ cycle, there is no immediate feedback of e.g. a change in leaf $\mathrm{N}$ to iWUE on a daily time scale, but there is a long term feedback by annual changes in vegetation structure and thus photosynthesis and $\mathrm{C}$ assimilation. 


\section{Results}

\section{Temporal trends}

Tree-ring $\delta^{13} \mathrm{C}$-derived iWUE calculated according to Eq. 1 shows a strongly increasing trend over the course of the $20^{\text {th }}$ century when averaged over all sites (Fig. 1a). This average iWUE was $64.2 \mu \mathrm{mol} / \mathrm{mol}$ for the first decade of the $20^{\text {th }}$ century and increased by $27.8 \%$ to 81.9 $\mu \mathrm{mol} / \mathrm{mol}$ for the last decade of the last century (Table 2). iWUE increased between these two periods at all sites, but to a varying degree, ranging from $+1.0 \%$ to $+53.1 \%$ (Table 1 ). While starting from a lower level, oak iWUE increased more strongly (by 32.4\%) compared to conifers (by $25.7 \%$, Table 2); this difference is, however, not significantly different owing to large site-to-site variability. The average iWUE values and increase for the two larch sites was similar to the evergreen conifers. The spread of the data expressed as standard deviation between all sites increased with time from $10.7 \mu \mathrm{mol} / \mathrm{mol}$ in $1901-1910$ to $13.8 \mu \mathrm{mol} / \mathrm{mol}$ in 1991-2000 (Table 2), also suggesting a non-uniform response, i.e. some sites responded more strongly than others.

The LPX standard model-run derived iWUE averaged over all plant functional types increased by $21.7 \%$ between the first and last decade of the $20^{\text {th }}$ century (Table 2 ), greater for oak $(24.5 \%)$ than for conifers $(20.6 \%)$ and for larch $(18.7 \%)$. The values in the standard run were below the tree-ring values by about $20-25 \%$, but showed many common features: particularly in the year-to-year, but also in the lower-frequency variability, such as plateaus in the general increasing trend in the 1900s, 1950s and 1990s (Fig. 1a, b, c). This resulted in a highly significant correlation between model and data regarding the temporal variations $\left(\mathrm{r}^{2}=\right.$ 0.60; $\mathrm{p}<0.001)$. When averages for all Europe (instead of just grid cells with tree-ring sites) are plotted, the agreement with the average tree-ring derived iWUE is even better $\left(r^{2}=0.62 ; p\right.$ $<0.001)$ with values often overlapping with the tree-ring derived range of iWUE. The greater 
agreement with the European model runs may be fortuitous, but the similar trends of the two model curves suggest that the site selection is appropriately representative for all Europe. A correlation analysis between model and tree-ring derived iWUE was also conducted for all individual sites, yielding generally high correlations with only a few exceptions (Fig. S1).

\section{Spatial patterns}

Averages for the first and the last decade of the $20^{\text {th }}$ century were also used to analyse the spatial iWUE patterns and their changes. Tree-ring derived iWUE shows a latitudinal gradient with increasing values from the North to the South for both decades, with the highest values observed in Turkey and southern Spain (Fig. 2a, b). This holds even though the results of different species are displayed together in this plot. The LPX model results (standard run without dynamic nitrogen cycle), too, show the North-South gradient and the general increase from 1901-1910 to 1991-2000 (Fig. 2c, d). Although model values are shifted to lower values as noted above, there is a qualitative agreement in the spatial patterns of tree-ring and model data illustrated by these maps. The correlation between independent model and tree-ring data sets (Fig. 3a) is highly significant (1901-1910: $\mathrm{r}^{2}=0.26 ; \mathrm{p}<0.01 ; 1991-2000: \mathrm{r}^{2}=0.30 ; \mathrm{p}<$ 0.001; combined: $\mathrm{r}^{2}=0.37, \mathrm{p}<0.001$, which is mainly driven by a strong relationship for the evergreen conifers $\left(r^{2}=0.67-0.69\right.$ for individual and combined periods, $\left.\mathrm{p}<0.001\right)$, but not for oak $\left(r^{2}=0.01-0.09\right)$.

While iWUE increased at all sites, this increase, however, was not uniform (Table 1; Fig. 4). The tree-ring data show relatively low increases for the southern and northern sites, while the highest values are mostly observed at sites with relatively temperate conditions in Central Europe (Fig. 4a). The model also shows a hotspot of increased iWUE in Central Europe, and additionally in some Mediterranean sub-regions (Fig. 4b). 
Different simulations were run to test the sensitivity of the modelled iWUE results. For example a simulation with dynamic $\mathrm{N}$ resulted in a better overall agreement between model and data (Fig. $\left.3 b ; r^{2}=0.48, p<0.001\right)$. We further investigated whether observed iWUE at the tree-ring sites was related to nitrogen deposition based on the map by Lamarque et al. (2011), which distinguishes between $\mathrm{NO}_{\mathrm{y}}, \mathrm{NH}_{\mathrm{x}}$ and total $\mathrm{N}\left(\mathrm{N}_{\text {tot }}\right)$. Current $\mathrm{N}_{\text {tot }}$ deposition averaged for 1991-2000 was not related to the spatial pattern of iWUE for the same period $\left(\mathrm{r}^{2}\right.$ $=0.05)$. However, significant correlations were found for the increase in iWUE to $\mathrm{NO}_{\mathrm{y}}, \mathrm{NH}_{\mathrm{x}}$ and $\mathrm{N}_{\text {tot }}\left(\mathrm{r}^{2}=0.17,0.18\right.$ and 0.19 , respectively; $\left.\mathrm{p}<0.01\right)$. Using the high-spatial resolution climate data set rather than the $0.5^{\circ} \times 0.5^{\circ} \mathrm{CRU}$ data resulted only in marginal differences in iWUE results (not shown). Model runs with constant $\mathrm{CO}_{2}$ fixed at the 1901-1910 level of 297 ppm and run with $20^{\text {th }}$ century climate data show only a small iWUE-increase between $1901-$ 1910 and $1991-2000$ of $3.1 \%$ for conifers and $7.6 \%$ for oaks, and even a decrease for larch (1.4\%). Averaged for all species (weighted by representation in the model), the increase at constant $\mathrm{CO}_{2}$ concentration (297 ppm) was $4.3 \%$ compared to $21.7 \%$ in the run with variable $\mathrm{CO}_{2}$ concentration (Table 2). This indicates that in the model $80.2 \%=((21.7-4.3) / 21.7) * 100$ of the increase between the investigated periods is due to the $\mathrm{CO}_{2}$-increase, and not due to climate or other factors. Also simulations with constant climate were performed: the resulting iWUE-increase when added to the results from the constant $\mathrm{CO}_{2}$-run was almost equal, but not identical (slightly higher) to the total iWUE-increase from the standard run, indicating some non-linearity in the model. An investigation of the influence of summer temperature and precipitation amount on iWUE at inter-annual time-scales in the model revealed that dry and warm conditions are associated with high iWUE, while cold and wet summer conditions are associated with lower iWUE (not shown). The inter-annual analysis is consistent with the spatial patterns in WUE across the European climatic gradients (Fig. 2).

\section{Climate relationships}


To explain the observed spatial pattern of change in iWUE, we analysed corresponding climate patterns in Europe over the same 1901-1910 to 1991-2000 periods. The best agreement between climate and iWUE patterns was found for changes in summer (JJA) precipitation over the $20^{\text {th }}$ century (Fig. 5 b) as well as changes in summer soil-water content (Fig. 5c). Regions with a summer drying trend are remarkably similar to the iWUE-change patterns of highly increasing values, both in model and empirical data (Fig. 4). In contrast, the change of the pattern for summer temperature is very different (Fig. 5a) and not congruent to the iWUE change, reflecting perhaps the indirect link between temperature and carbon isotope fractionation. This finding is further quantified by plotting the iWUE-changes versus the soilwater changes (Fig. 6). There is a significant negative relationship between JJA soil water changes and the tree-ring data (Fig. 6a, $\mathrm{r}^{2}=0.36, \mathrm{p}<0.01$ for the conifers; $\mathrm{r}^{2}=0.27, \mathrm{p}<0.01$ for all species combined; n.s. for oak), while no relationship was found with JJA temperature $\left(\mathrm{r}^{2}=0.00\right.$, all species combined). The model-derived iWUE-changes are also significantly related to soil water changes for all species (Fig. $6 b-c ; r^{2}=0.15-0.25 ; p<0.001$ ).

Our analysis of changes is based primarily on the comparison of the two periods 1901-10 and 1991-2000, which could be biased by specific climatic conditions during these periods. As a further verification of the observed relationships, we additionally carried out analysis based on the linear temporal iWUE-trends (\%-iWUE change per year). These results indicate that the iWUE-changes and trends are highly correlated (Fig. S2) and that the relationship between iWUE and summer soil-water content does not depend upon the particular metric for $20^{\text {th }}$ century change (Fig. S3). 


\section{Discussion}

\section{Observed iWUE patterns and trends}

We applied two independent methods to investigate changes in iWUE of trees across Europe and through the $20^{\text {th }}$ century, a period characterized by strongly increasing atmospheric $\mathrm{CO}_{2}$ concentrations and spatially inhomogeneous climatic changes. One method relies on carbon isotope variations in tree-rings from a network of sites, and the other on calculations of a complex vegetation model. Results from the two methods show remarkable agreement regarding the spatial patterns, namely the strong latitudinal gradient with low iWUE in the north and high iWUE in the south of the study region (Figs. 2, 3), as well as the temporal evolution of changes (Fig. 1; Table 1,2), characterized by an increasing trend in iWUE at almost all places. The general agreement between the two methods provides strong evidence for a wide-spread iWUE-increase in European forests over the $20^{\text {th }}$ century, and suggests important changes in the biosphere-climate interactions such as reduced transpiration for a given carbon uptake.

\section{The influence of climate and $\mathrm{CO}_{2}$}

The stationary spatial iWUE pattern and the corresponding latitudinal gradient is related to the summer temperature and precipitation variability in the model, showing higher iWUE for more water-stressed plants (growing in more arid conditions), consistent with studies of gasexchange and concurrent isotope measurements over climate gradients or seasonal variations (e.g. Moore et al., 1999, Panek \& Waring, 1997). It was observed for different species that when water stress resulted in stomatal closure, this was also reflected in decreasing carbon isotope discrimination as expected (Farquhar et al., 1982). However, surprisingly, we found the strongest increase of iWUE over the $20^{\text {th }}$ century not at the most southern sites, but rather at more temperate latitudes (Fig. 4). This phenomenon was simulated by the model as well as 
observed in the tree-ring derived data. Analysing spatial variability in summer climate trends revealed that this region is generally characterized by a drying trend, reflected in decreasing summer soil-water content (Figs. 5, 6). Our results therefore suggest that the trees (mainly conifers) underwent an accelerated increase in iWUE in this region, as the sum of the effects of increasing $\mathrm{CO}_{2}$ and soil drying, resulting in an effective reduction in stomatal conductance. A comparison of model simulations alternatively using observed and fixed (pre-industrial) $\mathrm{CO}_{2}$ concentrations reveals significant differences in the magnitude of iWUE response. The differences between these simulations allow the relative importance of climatic versus $\mathrm{CO}_{2}$ drivers to be attributed in the model results. Accordingly, about $80 \%$ of the average iWUE increase in European forests is due to increased $\mathrm{CO}_{2}$ (Table 2, constant $\mathrm{CO}_{2}$ run) and the remainder attributable to climatic change.

\section{Assumptions and uncertainties}

The application of dynamic vegetation model under a range of environmental conditions enables investigation of biosphere response to future environmental and climatic change scenarios, as well as the possibility to upscale these fluxes to larger spatial scales. Similarly, tree-ring stable isotopes provide an absolutely dated, replicable historical perspective on past carbon isotopic fractionation that may be coupled within modelling experiments to help evaluate and improve the model performance and resolve the nature/significance of key feedback mechanisms. But it is also important to stress that both the LPX model and the treering isotopic approach to calculating iWUE rely on numerous assumptions, and should be interpreted cautiously. Regarding the isotope-derived iWUE, while Seibt et al. (2008) have pointed out that iWUE and actual whole-plant WUE do not necessarily need to be related, it was recently confirmed that $\delta^{13} \mathrm{C}$ in tree-rings provides a good measure of transpiration to assimilation even on a seasonal scale (Michelot et al., 2011). Further, a large-scale eddy-flux assessment showed indeed wide-spread forest WUE increase at least for the last 10-15 years 
(Keenan et al., 2013). The use of the LPX helps to circumvent some of the limitations of the isotope approach, because we do not need to draw conclusions about actual fluxes, such as transpiration, directly from our tree-ring derived iWUE. Modelled iWUE was on average about $20 \%$ lower than the tree-ring derived values and also the increase from the beginning to the end of the $20^{\text {th }}$ century was somewhat lower in the model (Table 2). This suggests some uncertainties remain in the process and magnitude of iWUE responses both in the past and for the future. The agreement between model and data can vary depending on model assumptions, e.g. variable versus fixed vegetation, but also the values for the isotope offset used in Eq. 1 . We decided to use model settings from previous investigations (Spahni et al., 2013, Stocker et al., 2013), i.e. standard parameters, and not to optimize for best agreement between model and data, because this would involve some circular reasoning in testing modelled trends. Another implicit assumption of our study is that age-related trends are not significant. When trees grow in height, hydraulic resistance increases and turgor declines. This causes partial stomatal closure with an increase in iWUE, resulting in a reduction in height growth (Koch et al., 2004, Ryan \& Yoder, 1997). Accordingly, clear changes of isotope discrimination with tree height have been reported (McDowell et al., 2011). However, measuring carbon isotopes in stem wood sampled at breast height where an average of carbon from the whole canopy is collected does not seem to reflect this process. Evidence from several studies has shown that trees generally do not show any age-related $\delta^{13} \mathrm{C}$-trends after an initial juvenile phase of ca. 50 years (Francey \& Farquhar, 1982), which can be particularly well seen for trees that were living before the industrial $\mathrm{CO}_{2}$-concentration rise (Gagen et al., 2007, Loader et al., 2013). Furthermore, the vast majority of analyses were conducted on trees that were long-lived (> 250 years) additionally reducing the chances that the rapid juvenile increase in height or trends in $\delta^{13} \mathrm{C}$ ratios affect our $20^{\text {th }}$ century analyses. 
The wide-spread iWUE increase was likely caused by a reduction of stomatal conductance at the leaf level (Gagen et al., 2011). The results from the LPX model indeed suggest that the cause of the iWUE increase was reduced stomatal conductance during recent decades rather than increased assimilation (Fig. S4). However, the overall changes in canopy transpiration over the $20^{\text {th }}$ century remain unclear. Other effects of the $\mathrm{CO}_{2}$ fertilization like structural changes (such as increased leaf area) may compensate for the physiological response (reduced stomatal conductance) of plants to $\mathrm{CO}_{2}$ (Betts et al., 1997). It is probably unlikely that runoff increases of rivers have occurred as a result of a reduced transpiration flux leading to wetter soils (Huntington, 2008), in contrast to earlier findings (Gedney et al., 2006). Tree responses in our study can be compared with elevated $\mathrm{CO}_{2}$ /climate experiments with the caveat that such experimental studies have most often been conducted on juvenile trees (Wullschleger et al., 2002, Young et al., 2011) in $\mathrm{CO}_{2}$ concentration ranges from $380 \mathrm{ppm}$ to $500 \mathrm{ppm}$ or more over short timescales. In contrast, our investigation was performed on samples of old-growth trees from intact ecosystems that have experienced $\mathrm{CO}_{2}$ increases from 280 to $380 \mathrm{ppm}$ over the course of a century. It has been observed in fumigation experiments that elevated $\mathrm{CO}_{2}$ resulted in reduced stomatal conductance and therefore could ameliorate the negative effects of drought in many species through increased WUE (Ellsworth, 1999). A number of studies have reported such an increased plant-growth response to $\mathrm{CO}_{2}$ for trees growing under waterlimiting conditions (McMurtrie et al., 2008, Wullschleger et al., 2002). Direct evidence for a sustained adaptation remains limited and it is likely that the magnitude and rate of this response will depend upon species as well as local site conditions (Leuzinger \& Körner, 2007, Linares et al., 2009). A meta-analysis across different biomes did not detect a response in the radial growth, despite corresponding evidence for a significant and widespread increase in iWUE (Penuelas et al., 2011). 
We have considered that factors other than $\mathrm{CO}_{2}$ and water could also be important for explaining the observed iWUE-patterns and trends. Nitrogen is such a factor, representing one of the main nutrients for plant growth and a limiting factor in many ecosystems (Sun et al., 2010). The correlation between total $\mathrm{N}$ deposition and the tree-ring derived iWUE-increase in our network shows a significant relationship, and we can therefore not rule out the possibility that nitrogen deposition has partly contributed to the iWUE-increase in Central Europe. Further, our simulations with dynamical $\mathrm{N}$ improved correlations to tree-ring data (Fig. 3b). Other air pollutants, e.g. sulphur dioxide or ozone, may also influence tree physiological properties such as stomatal conductance and photosynthesis (Fairchild et al., 2009, Rinne et al., 2010). It was observed that long-term exposure of trees to background sulphur dioxide influenced carbon isotope signatures and iWUE of Abies alba Mill remote from industrial areas in western Germany (Boettger et al., 2014). However, through pollution reduction measures and legislation, the influence of nitrogen and especially sulphur is expected to further decrease in the future relative to climate change and $\mathrm{CO}_{2}$ effect.

\section{Large-scale implications}

Our finding of strongly increasing iWUE in regions of increasing summer drought is relevant in the context of refining projections of future climate development and carbon sequestration. It has been suggested that the drying trend in summer climate over Central and Southern Europe in recent decades is consistent with model-derived changes in mean summer precipitation as well as changes in the large-scale circulation, and that this trend might continue into the future (IPCC, 2013, Pal et al., 2004). Therefore, it is likely that trees in Central Europe will be exposed to even stronger drought stress in the future to which some species may be poorly adapted. Accordingly, shifts in species distribution may occur, as already observed e.g. in the Valais (Switzerland), where the current drought-induced decline of Scots pine leads to a transition of these forests into mixed oak-deciduous at lower 
elevations and spruce-fir forests at higher elevations (Bigler et al., 2006). Water has been identified as a major issue in a high- $\mathrm{CO}_{2}$ world, with the question raised if the effect of elevated $\mathrm{CO}_{2}$ on forest vegetation is "more a water issue than a carbon issue" (Holtum \& Winter, 2010), emphasizing the strong link between carbon and water cycles. Landatmosphere interactions, soil-moisture-precipitation and temperature feedbacks play a crucial role in determining future summer climate variability (Seneviratne et al., 2006). Model and empirical studies clearly show the importance of biosphere/carbon-cycle feedbacks (Frank et al., 2010) and physiological forcing by $\mathrm{CO}_{2}$ for predicting future climate (Cao et al., 2010). However, the magnitudes of such feedbacks are still highly uncertain and due to a lack of basic understanding of relevant processes, terrestrial carbon models differ in their response to climate change (Frank et al., 2010, Plattner et al., 2008). Our study enables an assessment of a complex vegetation model with empirical data, which may ultimately lead to model improvements and better estimations of vegetation-climate feedbacks.

Acknowledgments: This study was supported by the EC projects ISONET (EVK2-CT-200200147) and Millennium (FP6-2004-GLOBAL-017008-2) and by the Swiss National Science Foundation (SNFS) iTREE-project (CRSII3_136295). FJ acknowledges support by SNFS and NCCR Climate and by the European Commission through the FP7 projects Past4Future (grant no. 243908) and CARBOCHANGE (grant 436 no. 264879). MS acknowledges SNFS-project 134864, NJL, IR C3W and NE/B501504, GH: ICLEA-Helmholtz Association, BMBF0315427B. 


\section{References}

Ainsworth EA, Long SP (2005) What have we learned from 15 years of free-air $\mathrm{CO}_{2}$ enrichment (FACE)? A meta-analytic review of the responses of photosynthesis, canopy. New Phytologist, 165, 351-371.

Allen CD, Macalady AK, Chenchouni H et al. (2010) A global overview of drought and heatinduced tree mortality reveals emerging climate change risks for forests. Forest Ecology and Management, 259, 660-684.

Andreu-Hayles L, Planells O, Gutierrez E, Muntan E, Helle G, Anchukaitis KJ, Schleser GH (2011) Long tree-ring chronologies reveal $20^{\text {th }}$ century increases in water-use efficiency but no enhancement of tree growth at five Iberian pine forests. Global Change Biology, 17, 2095-2112.

Babst F, Poulter B, Trouet V et al. (2013) Site- and species-specific responses of forest growth to climate across the European continent. Global Ecology and Biogeography, 22, 706-717.

Betts RA, Cox PM, Lee SE, Woodward FI (1997) Contrasting physiological and structural vegetation feedbacks in climate change simulations. Nature, 387, 796-799.

Bigler C, Bräker OU, Bugmann H, Dobbertin M, Rigling A (2006) Drought as an inciting mortality factor in Scots pine stands of the Valais, Switzerland. Ecosystems, 9, 330 343.

Boettger T, Haupt M, Friedrich M, Waterhouse JS (2014) Reduced climate sensitivity of carbon, oxygen and hydrogen stable isotope ratios in tree-ring cellulose of silver fir (Abies alba Mill.) influenced by background $\mathrm{SO}_{2}$ in Franconia (Germany, Central Europe). Environmental Pollution, 185, 281-294.

Boettger T, Haupt M, Knöller K et al. (2007) Wood cellulose preparation methods and mass spectrometric analyses of $\delta^{13} \mathrm{C}, \delta^{18} \mathrm{O}$, and nonexchangeable $\delta^{2} \mathrm{H}$ values in cellulose, sugar, and starch: An interlaboratory comparison. Analytical Chemistry, 79, 46034612.

Borella S, Leuenberger M, Saurer M, Siegwolf R (1998) Reducing uncertainties in $\delta^{13} \mathrm{C}$ analysis of tree rings: Pooling, milling, and cellulose extraction. Journal of Geophysical Research Atmospheres, 103, 19519-19526.

Cao L, Bala G, Caldeira K, Nemani R, Ban-Weiss G (2010) Importance of carbon dioxide physiological forcing to future climate change. Proceedings of the National Academy of Sciences of the United States of America, 107, 9513-9518.

Cook ER, Peters K (1981) The smoothing spline: a new approach to standardizing forest interior tree-ring width series for dendroclimatic studies. Tree Ring Bulletin, 41, 4553.

De Kauwe MG, Medlyn BE, Zaehle S et al. (2013) Forest water use and water use efficiency at elevated $\mathrm{CO}_{2}$ : a model-data intercomparison at two contrasting temperate forest FACE sites. Global Change Biology, 19, 1759-1779.

Ehleringer JR, Cerling TE (1995) Atmospheric $\mathrm{CO}_{2}$ and the ratio of intercellular to ambient $\mathrm{CO}_{2}$ concentrations in plants. Tree Physiology, 15, 105-111.

Ellsworth DS (1999) $\mathrm{CO}_{2}$ enrichment in a maturing pine forest: are $\mathrm{CO}_{2}$ exchange and water status in the canopy affected? Plant Cell and Environment, 22, 461-472.

Fairchild IJ, Loader NJ, Wynn PM et al. (2009) Sulfur fixation in wood mapped by synchrotron X-ray studies: implications for environmental archives. Environmental Science \& Technology, 43, 1310-1315.

Farquhar GD, Caemmerer SV, Berry JA (1980) A biochemical model of photosynthetic $\mathrm{CO}_{2}$ assimilation in leaves of $C_{3}$ species. Planta, 149, 78-90. 
Farquhar GD, O'Leary MH, Berry JA (1982) On the relationship between carbon isotope discrimination and the intercellular carbon dioxide concentration in leaves. Australian Journal of Plant Physiology, 9, 121-137.

Feng XH (1998) Long-term $\mathrm{c}_{\mathrm{i}} / \mathrm{c}_{\mathrm{a}}$ response of trees in western North America to atmospheric $\mathrm{CO}_{2}$ concentration derived from carbon isotope chronologies. Oecologia, 117, 19-25.

Francey RJ, Farquhar GD (1982) An explanation of ${ }^{13} \mathrm{C} /{ }^{12} \mathrm{C}$ variations in tree rings. Nature, 297, 28-31.

Frank DC, Esper J, Raible CC, Büntgen U, Trouet V, Stocker B, Joos F (2010) Ensemble reconstruction constraints on the global carbon cycle sensitivity to climate. Nature, 463, 527-U143.

Gagen M, Finsinger W, Wagner-Cremer F et al. (2011) Evidence of changing intrinsic wateruse efficiency under rising atmospheric $\mathrm{CO}_{2}$ concentrations in Boreal Fennoscandia from subfossil leaves and tree ring $\delta^{13} \mathrm{C}$ ratios. Global Change Biology, 17, 1064 1072.

Gagen M, McCarroll D, Loader NJ, Robertson L, Jalkanen R, Anchukaitis KJ (2007) Exorcising the 'segment length curse': Summer temperature reconstruction since AD 1640 using non-detrended stable carbon isotope ratios from pine trees in northern Finland. Holocene, 17, 435-446.

Gedney N, Cox PM, Betts RA, Boucher O, Huntingford C, Stott PA (2006) Detection of a direct carbon dioxide effect in continental river runoff records. Nature, 439, 835-838.

Gerber S, Joos F, Brugger P, Stocker TF, Mann ME, Sitch S, Scholze M (2003) Constraining temperature variations over the last millennium by comparing simulated and observed atmospheric $\mathrm{CO}_{2}$. Climate Dynamics, 20, 281-299.

Gerten D, Schaphoff S, Haberlandt U, Lucht W, Sitch S (2004) Terrestrial vegetation and water balance - hydrological evaluation of a dynamic global vegetation model. Journal of Hydrology, 286, 249-270.

Gessler A, Brandes E, Buchmann N, Helle G, Rennenberg H, Barnard RL (2009) Tracing carbon and oxygen isotope signals from newly assimilated sugars in the leaves to the tree-ring archive. Plant Cell and Environment, 32, 780-795.

Haxeltine A, Prentice IC (1996) BIOME3: An equilibrium terrestrial biosphere model based on ecophysiological constraints, resource availability, and competition among plant functional types. Global Biogeochemical Cycles, 10, 693-709.

Hickler T, Smith B, Prentice IC, Mjofors K, Miller P, Arneth A, Sykes MT (2008) CO 2 fertilization in temperate FACE experiments not representative of boreal and tropical forests. Global Change Biology, 14, 1531-1542.

Hietz P, Wanek W, Dunisch O (2005) Long-term trends in cellulose $\delta^{13} \mathrm{C}$ and water-use efficiency of tropical Cedrela and Swietenia from Brazil. Tree Physiology, 25, 745752.

Hijmans RJ, Cameron SE, Parra JL, Jones PG, Jarvis A (2005) Very high resolution interpolated climate surfaces for global land areas. International Journal of Climatology, 25, 1965-1978.

Holtum JAM, Winter K (2010) Elevated $\left[\mathrm{CO}_{2}\right]$ and forest vegetation: more a water issue than a carbon issue? Functional Plant Biology, 37, 694-702.

Huntington TG (2008) $\mathrm{CO}_{2}$-induced suppression of transpiration cannot explain increasing runoff. Hydrological Processes, 22, 311-314.

IPCC (2013) Climate Change 2013: The Physical Science Basis. Contribution of Working Group I to the Fifth Assessment Report of the Intergovernmental Panel on Climate Change, Cambridge, United Kingdom and New York, NY, USA, Cambridge University Press. 
Joos F, Gerber S, Prentice IC, Otto-Bliesner BL, Valdes PJ (2004) Transient simulations of Holocene atmospheric carbon dioxide and terrestrial carbon since the Last Glacial Maximum. Global Biogeochemical Cycles, 18, 10.1029/2003gb002156.

Joos F, Prentice IC, Sitch S et al. (2001) Global warming feedbacks on terrestrial carbon uptake under the Intergovernmental Panel on Climate Change (IPCC) emission scenarios. Global Biogeochemical Cycles, 15, 891-907.

Keenan TF, Hollinger DY, Bohrer G, Dragoni D, Munger JW, Schmid HP, Richardson AD (2013) Increase in forest water-use efficiency as atmospheric carbon dioxide concentrations rise. Nature, 499, 324-327.

Koch GW, Sillett SC, Jennings GM, Davis SD (2004) The limits to tree height. Nature, 428, 851-854.

Lamarque J-F, Kyle GP, Meinshausen M et al. (2011) Global and regional evolution of shortlived radiatively-active gases and aerosols in the Representative Concentration Pathways. Climatic Change, 109, 191-212.

Leavitt SW, Long A (1984) Sampling strategy for stable carbon isotope analysis of tree rings in pine. Nature, 311 145-147.

Leuenberger M (2007) To what extent can ice core data contribute to the understanding of plant ecological developments of the past? In: Stable Isotopes as Indicators of Ecological Change. (eds Dawson TE, Siegwolf RTW) pp 211-233. London, Elsevier Academic Press.

Leuzinger S, Körner C (2007) Water savings in mature deciduous forest trees under elevated $\mathrm{CO}_{2}$. Global Change Biology, 13, 2498-2508.

Linares J-C, Delgado-Huertas A, Julio Camarero J, Merino J, Carreira JA (2009) Competition and drought limit the response of water-use efficiency to rising atmospheric carbon dioxide in the Mediterranean fir Abies pinsapo. Oecologia, 161, 611-624.

Loader NJ, Robertson I, McCarroll D (2003) Comparison of stable carbon isotope ratios in the whole wood, cellulose and lignin of oak tree-rings. Palaeogeography Palaeoclimatology Palaeoecology, 196, 395-407.

Loader NJ, Walsh RPD, Robertson I et al. (2011) Recent trends in the intrinsic water-use efficiency of ringless rainforest trees in Borneo. Philosophical Transactions of the Royal Society B-Biological Sciences, 366, 3330-3339.

Loader NJ, Young GHF, Grudd H, McCarroll D (2013) Stable carbon isotopes from Torneträsk, northern Sweden provide a millennial length reconstruction of summer sunshine and its relationship to Arctic circulation. Quaternary Science Reviews, 62, 97-113.

Marshall JD, Monserud RA (1996) Homeostatic gas-exchange parameters inferred from ${ }^{13} \mathrm{C} /{ }^{12} \mathrm{C}$ in tree rings of conifers. Oecologia, 105, 13-21.

McCarroll D, Loader NJ (2004) Stable isotopes in tree rings. Quaternary Science Reviews, 23, 771-801.

McDowell N, Bond B, Dickman L, Ryan M, Whitehead D (2011) Relationships between tree height and carbon isotope discrimination. In: Size- and Age-Related Changes in Tree

Structure. (eds Meinzer F, Lachenbruch B, Dawson T) pp 255-286. Dordrecht, the Netherlands, Springer.

McMurtrie RE, Norby RJ, Medlyn BE, Dewar RC, Pepper DA, Reich PB, Barton CVM (2008) Why is plant-growth response to elevated $\mathrm{CO}_{2}$ amplified when water is limiting, but reduced when nitrogen is limiting? A growth-optimisation hypothesis. Functional Plant Biology, 35, 521-534.

Michelot A, Eglin T, Dufrene E, Lelarge-Trouverie C, Damesin C (2011) Comparison of seasonal variations in water-use efficiency calculated from the carbon isotope composition of tree rings and flux data in a temperate forest. Plant Cell and Environment, 34, 230-244. 
Mitchell TD, Jones PD (2005) An improved method of constructing a database of monthly climate observations and associated high-resolution grids. International Journal of Climatology, 25, 693-712.

Moore DJ, Nowak RS, Tausch RJ (1999) Gas exchange and carbon isotope discrimination of Juniperus osteosperma and Juniperus occidentalis across environmental gradients in the Great Basin of western North America. Tree Physiology, 19, 421-433.

Murray SJ, Foster PN, Prentice IC (2011) Evaluation of global continental hydrology as simulated by the Land-surface Processes and eXchanges Dynamic Global Vegetation Model. Hydrology and Earth System Sciences, 15, 91-105.

Norby RJ, Warren JM, Iversen CM, Medlyn BE, McMurtrie RE (2010) $\mathrm{CO}_{2}$ enhancement of forest productivity constrained by limited nitrogen availability. Proceedings of the National Academy of Sciences of the United States of America, 107, 19368-19373.

Pal JS, Giorgi F, Bi XQ (2004) Consistency of recent European summer precipitation trends and extremes with future regional climate projections. Geophysical Research Letters, 31, 10.1029/2004g1019836.

Pan Y, Birdsey RA, Fang J et al. (2011) A large and persistent carbon sink in the world's forests. Science, 333, 988-993.

Panek JA, Waring RH (1997) Stable carbon isotopes as indicators of limitations to forest growth imposed by climate stress. Ecological Applications, 7, 854-863.

Parmesan C, Yohe G (2003) A globally coherent fingerprint of climate change impacts across natural systems. Nature, 421, 37-42.

Penuelas J, Canadell JG, Ogaya R (2011) Increased water-use efficiency during the $20^{\text {th }}$ century did not translate into enhanced tree growth. Global Ecology and Biogeography, 20, 597-608.

Plattner GK, Knutti R, Joos F et al. (2008) Long-term climate commitments projected with climate-carbon cycle models. Journal of Climate, 21, 2721-2751.

Rinne KT, Loader NJ, Switsur VR, Treydte KS, Waterhouse JS (2010) Investigating the influence of sulphur dioxide $\left(\mathrm{SO}_{2}\right)$ on the stable isotope ratios $\left(\delta^{13} \mathrm{C}\right.$ and $\left.\delta^{18} \mathrm{O}\right)$ of tree rings. Geochimica Et Cosmochimica Acta, 74, 2327-2339.

Ryan MG, Yoder BJ (1997) Hydraulic limits to tree height and tree growth. Bioscience, 47, 235-242.

Saurer M, Aellen K, Siegwolf R (1997) Correlating $\delta^{13} \mathrm{C}$ and $\delta^{18} \mathrm{O}$ in cellulose of trees. Plant Cell and Environment, 20, 1543-1550.

Saurer M, Siegwolf RTW, Schweingruber FH (2004) Carbon isotope discrimination indicates improving water-use efficiency of trees in northern Eurasia over the last 100 years. Global Change Biology, 10, 2109-2120.

Schimel DS, House JI, Hibbard KA et al. (2001) Recent patterns and mechanisms of carbon exchange by terrestrial ecosystems. Nature, 414, 169-172.

Seibt U, Rajabi A, Griffiths H, Berry JA (2008) Carbon isotopes and water use efficiency: sense and sensitivity. Oecologia, 155, 441-454.

Seneviratne SI, Luethi D, Litschi M, Schaer C (2006) Land-atmosphere coupling and climate change in Europe. Nature, 443, 205-209.

Sitch S, Smith B, Prentice IC et al. (2003) Evaluation of ecosystem dynamics, plant geography and terrestrial carbon cycling in the LPJ dynamic global vegetation model. Global Change Biology, 9, 161-185.

Spahni R, Joos F, Stocker BD, Steinacher M, Yu ZC (2013) Transient simulations of the carbon and nitrogen dynamics in northern peatlands: from the Last Glacial Maximum to the 21st century. Climate of the Past, 9, 1287-1308.

Stocker BD, Roth R, Joos F et al. (2013) Multiple greenhouse-gas feedbacks from the land biosphere under future climate change scenarios. Nature Climate Change, 3, 666-672. 
Stocker BD, Strassmann K, Joos F (2011) Sensitivity of Holocene atmospheric $\mathrm{CO}_{2}$ and the modern carbon budget to early human land use: analyses with a process-based model. Biogeosciences, 8, 69-88.

Strassmann KM, Joos F, Fischer G (2008) Simulating effects of land use changes on carbon fluxes: past contributions to atmospheric $\mathrm{CO}_{2}$ increases and future commitments due to losses of terrestrial sink capacity. Tellus Series B-Chemical and Physical Meteorology, 60, 583-603.

Sun F, Kuang Y, Wen D, Xu Z, Li J, Zuo W, Hou E (2010) Long-term tree growth rate, water use efficiency, and tree ring nitrogen isotope composition of Pinus massoniana L. in response to global climate change and local nitrogen deposition in Southern China. Journal of Soils and Sediments, 10, 1453-1465.

Tian HQ, Chen GS, Liu ML et al. (2010) Model estimates of net primary productivity, evapotranspiration, and water use efficiency in the terrestrial ecosystems of the southern United States during 1895-2007. Forest Ecology and Management, 259, 1311-1327.

Treydte K, Frank D, Esper J et al. (2007) Signal strength and climate calibration of a European tree ring isotope network. Geophysical Research Letters, 34, doi:10.1029/2007GL031106.

Wania R, Ross I, Prentice IC (2009) Integrating peatlands and permafrost into a dynamic global vegetation model: 1. Evaluation and sensitivity of physical land surface processes. Global Biogeochemical Cycles, 23, 10.1029/2008gb003412.

Waterhouse JS, Switsur VR, Barker AC, Carter AHC, Hemming DL, Loader NJ, Robertson I (2004) Northern European trees show a progressively diminishing response to increasing atmospheric carbon dioxide concentrations. Quaternary Science Reviews, 23, 803-810.

Wullschleger SD, Tschaplinski TJ, Norby RJ (2002) Plant water relations at elevated $\mathrm{CO}_{2^{-}}$ implications for water-limited environments. Plant Cell and Environment, 25, 319331.

Xu-Ri, Prentice IC (2008) Terrestrial nitrogen cycle simulation with a dynamic global vegetation model. Global Change Biology, 14, 1745-1764.

Xu-Ri, Prentice IC, Spahni R, Niu HS (2012) Modelling terrestrial nitrous oxide emissions and implications for climate feedback. New Phytologist, 196, 472-488.

Young GHF, Demmler JC, Gunnarson BE, Kirchhefer AJ, Loader NJ, McCarroll D (2011) Age trends in tree ring growth and isotopic archives: A case study of Pinus sylvestris L. from northwestern Norway. Global Biogeochemical Cycles, 25, 10.1029/2010gb003913.

Zhao M, Running SW (2010) Drought-induced reduction in global terrestrial net primary production from 2000 through 2009. Science, 329, 940-943. 


\section{Supporting Information}

Table S1: Long-term annual temperature and precipitation for all study sites.

Figure S1: Correlation analysis between the 35 tree-ring derived iWUE time-series from 1901-2000 and the output from the LPX model standard run for the nearest pixel.

Figure S2: Relationship between iWUE change in \% (calculated as the relative difference between iWUE in the periods 1901-10 and 1991-2000) and the iWUE trends (slope of the linear regression between iWUE and time for 1901 to 2000) for each tree-ring site.

Figure S3: The iWUE trends for the tree-ring sites as a function of the $20^{\text {th }}$ century trends in summer (JJA) soil-water content (SWC).

Figure S4: LPX standard model calculated assimilation and stomatal conductance averaged for all Europe. 


\section{Table 1}

Site information including site coordinates, site name, site code, country, species, altitude and iWUE-increase between the periods 1901-1910 and 1991-2000. Twenty chronologies indicated by a star $(*)$ were established during the ISONET-project (Treydte et al., 2007) and 15 additional sites during the Millennium-project (see methods for details). The sites are listed from south to north.

\begin{tabular}{|c|c|c|c|c|c|c|c|c|}
\hline No. & ${ }^{\circ} \mathbf{E}$ & ${ }^{\circ} \mathbf{N}$ & Site name & Code & Country & Species & $\begin{array}{l}\text { Alt. } \\
{[\mathrm{m}]}\end{array}$ & $\begin{array}{c}\text { iWUE } \\
{[\%]}\end{array}$ \\
\hline 1 & 30.02 & 36.60 & Elmali & Elm & Turkey & Juniperus excelsa & 1937 & 20.5 \\
\hline 2 & -2.95 & 37.80 & Cazorla & $\mathrm{Caz}^{*}$ & Spain & Pinus nigra & 1816 & 21.9 \\
\hline 3 & 16.20 & 39.93 & Serra di Cris. & Ser* & Italy & Pinus leucodermis & 1900 & 20.3 \\
\hline 4 & 1.70 & 42.23 & Pedraforca & Ped* & Spain & Pinus uncinata & 2100 & 21.5 \\
\hline 5 & -5.25 & 43.07 & Pinar de Lillo & $\mathrm{Lil}^{*}$ & Spain & Pinus sylvestris & 1600 & 33.9 \\
\hline 6 & 11.66 & 45.98 & Trento & Tre & Italy & Picea abies & 1150 & 29.6 \\
\hline 7 & 8.60 & 46.35 & Cavergno & $\mathrm{Cav}^{*}$ & Switzerland & Quercus petraea & 900 & 25.9 \\
\hline 8 & 13.69 & 46.37 & Veza & Vez & Slovenia & Larix decidua & 1700 & 27.1 \\
\hline 9 & 7.80 & 46.43 & Lötschental & Loe & Switzerland & Larix decidua & 2100 & 24.3 \\
\hline 10 & 8.77 & 46.50 & Vigera & Vig* & Switzerland & Pinus sylvestris & 1400 & 29.5 \\
\hline 11 & 13.36 & 47.28 & Dachstein & Dac & Austria & Pinus cembra & 1900 & 27.2 \\
\hline 12 & 16.06 & 47.95 & Poellau & Poe* & Austria & Pinus nigra & 500 & 22.8 \\
\hline 13 & 16.20 & 48.18 & Lainzer Tierg. & Lai* & Austria & Quercus petraea & 300 & 33.7 \\
\hline 14 & -1.70 & 48.25 & Rennes & Ren* & France & Quercus robur & 100 & 24.3 \\
\hline 15 & 2.67 & 48.38 & Fontainebleau & Fon* & France & Quercus petraea & 100 & 28.3 \\
\hline 16 & 11.00 & 49.15 & Franconia & Fra & Germany & Abies alba & 394 & 53.1 \\
\hline 17 & 20.38 & 50.12 & Niopol. Gibiel & $\mathrm{Nie}^{*}$ & Poland & Quercus robur & 190 & 30.3 \\
\hline 18 & -0.59 & 51.41 & Windsor & Win* & UK & Pinus sylvestris & 10 & 43.8 \\
\hline 19 & 9.78 & 51.50 & Dransfeld & Dra* & Germany & Quercus petraea & 320 & 39.8 \\
\hline 20 & -0.59 & 51.98 & Woburn & Wob* & UK & Quercus robur & 50 & 29.3 \\
\hline 21 & 0.50 & 52.83 & Sandringham & San & UK & Quercus robur & 56 & 30.2 \\
\hline 22 & 22.93 & 54.10 & Suwalki & Suw* & Poland & Pinus sylvestris & 160 & 39.8 \\
\hline 23 & 23.97 & 54.88 & Pane. Silas & Pan* & Lithuania & Pinus sylvestris & 45 & 42.9 \\
\hline 24 & -3.43 & 55.27 & Lochwood & Loc & UK & Quercus robur & 175 & 28.1 \\
\hline 25 & -5.43 & 57.10 & Southern Upl. & Sup & UK & Pinus sylvestris & 160 & 25.2 \\
\hline 26 & 23.08 & 60.00 & Bromarv & Bro* & Finland & Quercus robur & 5 & 41.9 \\
\hline 27 & 22.17 & 60.41 & Turku & Tur & Finland & Quercus robur & 20 & 44.3 \\
\hline 28 & 12.18 & 62.00 & Gutuli & Gut* & Norway & Pinus sylvestris & 800 & 24.1 \\
\hline 29 & 31.27 & 62.98 & Ilomantsi & Ilo* & Finland & Pinus sylvestris & 200 & 17.9 \\
\hline 30 & 13.50 & 63.16 & Furuberget & Fur & Sweden & Pinus sylvestris & 650 & 10.4 \\
\hline 31 & 33.15 & 67.41 & Khibiny & Khi & Russia & Pinus sylvestris & 300 & 19.8 \\
\hline 32 & 19.72 & 68.22 & Torneträsk & Tor & Sweden & Pinus sylvestris & 400 & 15.7 \\
\hline 33 & 27.50 & 68.50 & Laanila & Laa & Finland & Pinus sylvestris & 220 & 20.1 \\
\hline 34 & 15.72 & 68.79 & Forfjorddalen & For & Norway & Pinus sylvestris & 110 & 1.0 \\
\hline 35 & 28.32 & 68.93 & Kessi, Inari & Ina* & Finland & Pinus sylvestris & 150 & 24.1 \\
\hline
\end{tabular}


Table 2

Average iWUE values ( \pm standard deviation) for 1901-1910 and 1991-2000 and the change between these periods for individual species and over all sites for tree-ring derived data (Eq. 1), the standard LPX model run and a model run with constant $\mathrm{CO}_{2}$ (the average for 19011910, i.e. 297 ppm).

\begin{tabular}{|c|c|c|c|c|}
\hline Data type & Species & $\begin{array}{c}\text { iWUE } \\
1901-1910 \\
{\left[\mu \mathrm{mol} \mathrm{mol}{ }^{-1}\right]}\end{array}$ & 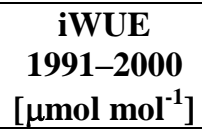 & $\begin{array}{c}\text { iWUE } \\
\text { change } \\
{[\%]}\end{array}$ \\
\hline Tree-ring data & conifers & $67.6 \pm 11.1$ & $85.0 \pm 15.5$ & $25.7 \pm 11.6$ \\
\hline Tree-ring data & larch & $65.5 \pm 0.4$ & $82.4 \pm 1.9$ & $25.7 \pm 2.0$ \\
\hline Tree-ring data & oak & $57.3 \pm 7.1$ & $75.7 \pm 8.9$ & $32.4 \pm 6.7$ \\
\hline Tree-ring data & all & $64.2 \pm 10.7$ & $81.9 \pm 13.8$ & $27.8 \pm 10.3$ \\
\hline Model & conifers & $54.0 \pm 15.4$ & $64.6 \pm 17.0$ & $20.6 \pm 9.3$ \\
\hline Model & larch & $41.5 \pm 2.6$ & $48.4 \pm 1.6$ & $18.7 \pm 9.4$ \\
\hline Model & oak & $55.8 \pm 12.6$ & $69.2 \pm 14.7$ & $24.5 \pm 6.7$ \\
\hline Model & all & $53.8 \pm 14.2$ & $65.1 \pm 16.2$ & $21.7 \pm 8.5$ \\
\hline Model const. $\mathrm{CO}_{2}$ & conifers & $53.8 \pm 15.3$ & $55.2 \pm 14.8$ & $3.1 \pm 8.0$ \\
\hline Model const. $\mathrm{CO}_{2}$ & larch & $41.4 \pm 2.6$ & $40.6 \pm 1.7$ & $-1.4 \pm 10.4$ \\
\hline Model const. $\mathrm{CO}_{2}$ & oak & $55.6 \pm 12.6$ & $59.7 \pm 13.0$ & $7.6 \pm 6.2$ \\
\hline Model const. $\mathrm{CO}_{2}$ & all & $53.6 \pm 14.2$ & $55.8 \pm 14.3$ & $4.3 \pm 7.8$ \\
\hline
\end{tabular}




\section{Figure captions}

\section{Fig. 1}

(a) Temporal evolution of average tree-ring derived iWUE ('data'; \pm standard error of site variability as dotted lines), LPX standard model run iWUE averaged over all tree-ring sites ('model sites') and for all Europe with species represented by weight ('model Europe'); (b) the same data after high-pass filtering, and (c) low-pass-filtering with the variance scaled to 1.

\section{Fig. 2}

Tree-ring derived iWUE for all sites in 1901-1910 (a) and in 1991-2000 in (b). LPX-modelderived iWUE in 1901-1910 (c) and in 1991-2000 (d) combined for all tree species.

\section{Fig. 3}

Tree-ring derived iWUE (empirical data) plotted against LPX model iWUE, combining the data from 1901-1910 (closed symbols) and 1991-2000 (open symbols) by tree-species groups. Two model versions have been used: a) standard simulation b) and simulation with dynamical nitrogen $(\mathrm{N})$. Regression lines for the correlation combining all data are shown.

\section{Fig. 4}

The change in iWUE between 1901-1910 and 1991-2000 derived from tree-ring (a) and from model data (b). The colour code shows the change in iWUE expressed as the relative change compared to $1901-1910$.

\section{Fig. 5}

Climate change in Europe shown as differences between 1991-2000 and 1901-1910 for summer (JJA) temperature (a), summer precipitation (b) and summer soil-water content (c). Temperature and precipitation data are from the CRU TS 3.1 data set and soil water content is LPX model output. 
Fig. 6

The iWUE change from 1901-1910 to 1991-2000 as a function of the change in summer (JJA) soil-water content (SWC) for a) data of all tree-ring sites, and b) the modelled conifer, c) modelled oak, and d) modelled larch results. In the model plots b) - d) there are data outside the displayed range which are not shown. 
Figure 1

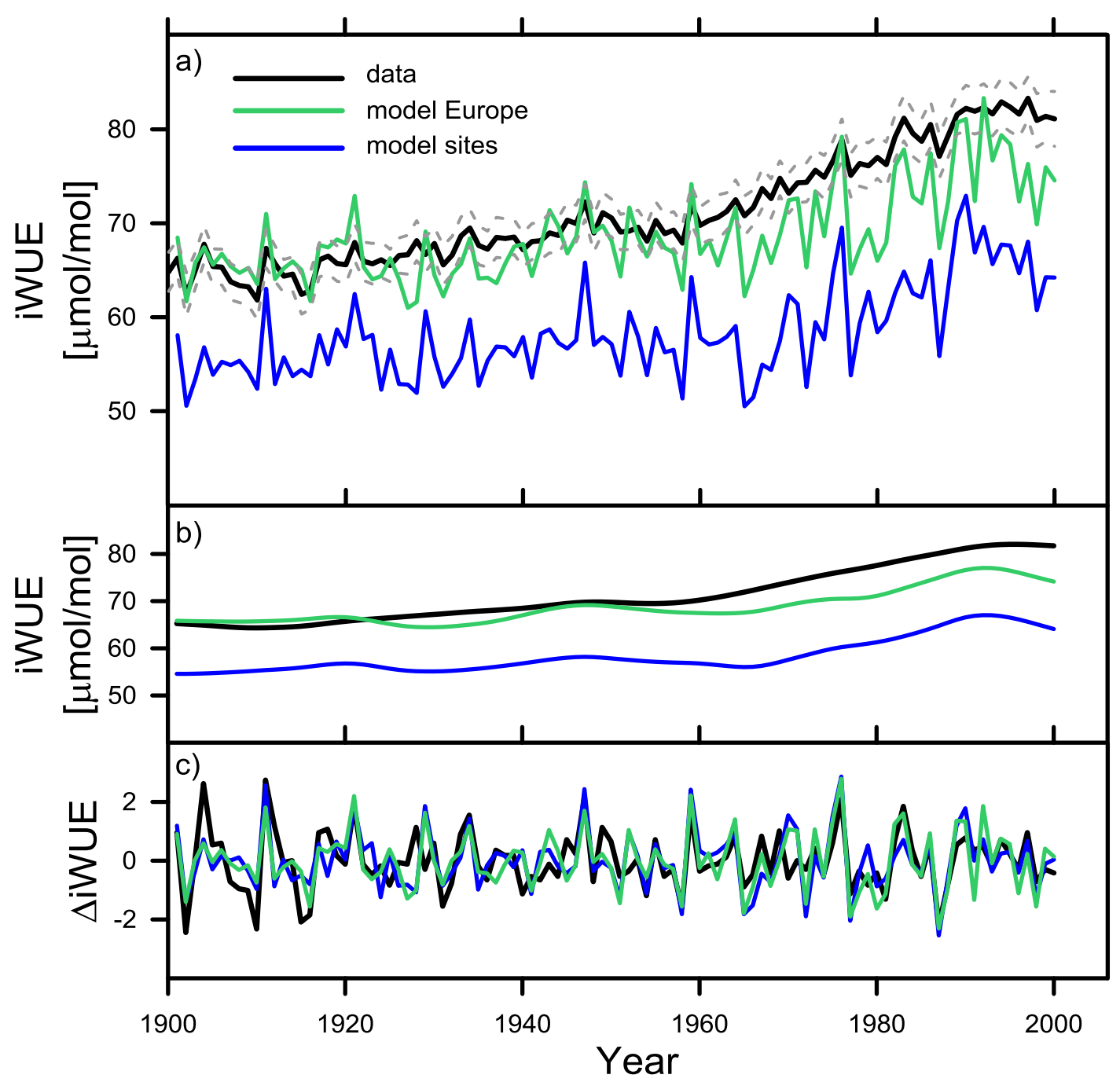


Figure 2
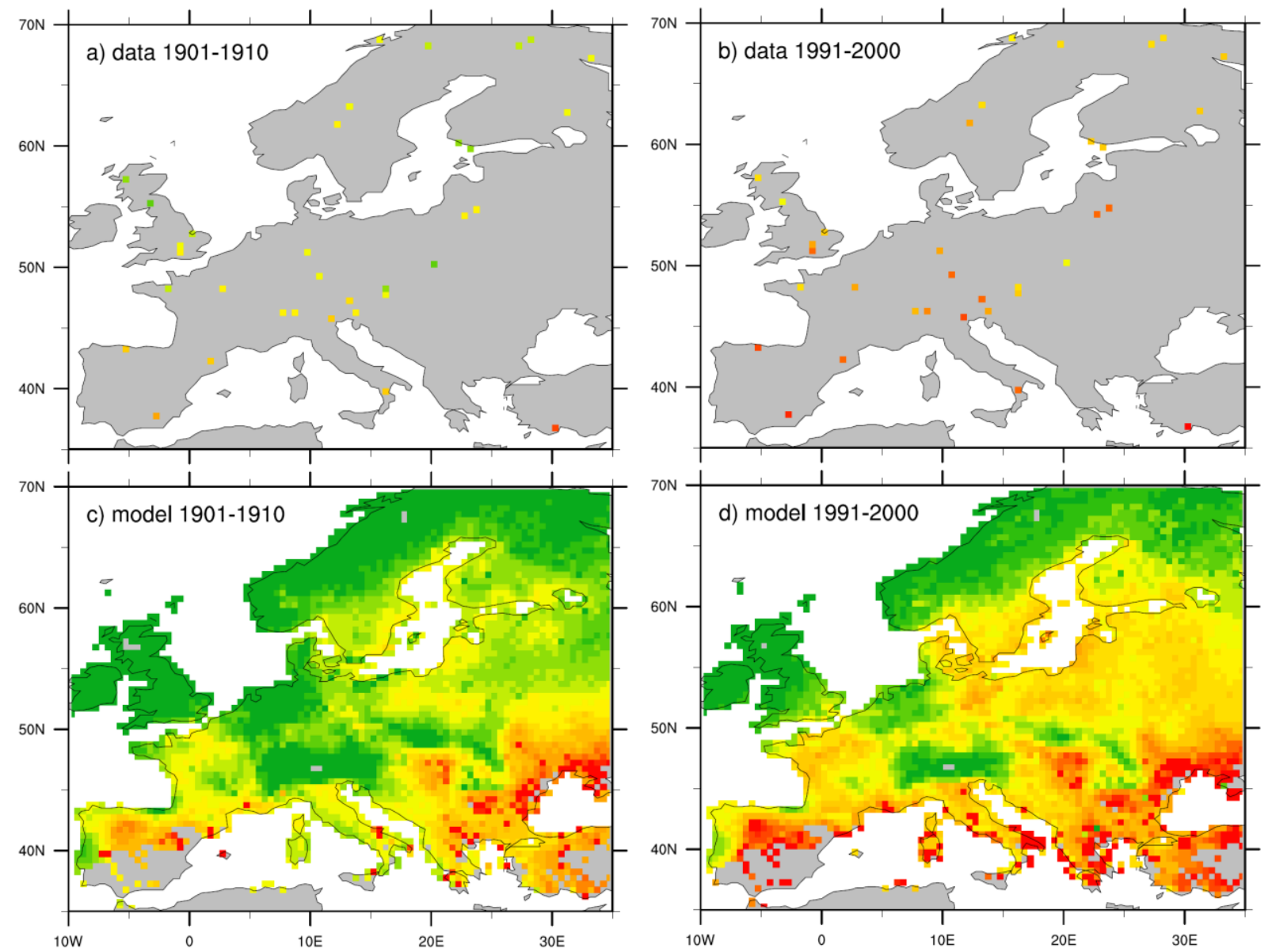

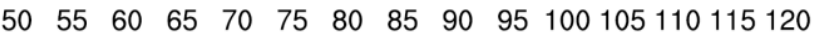
iWUE $[\mu \mathrm{mol} / \mathrm{mol}]$ 
Figure 3

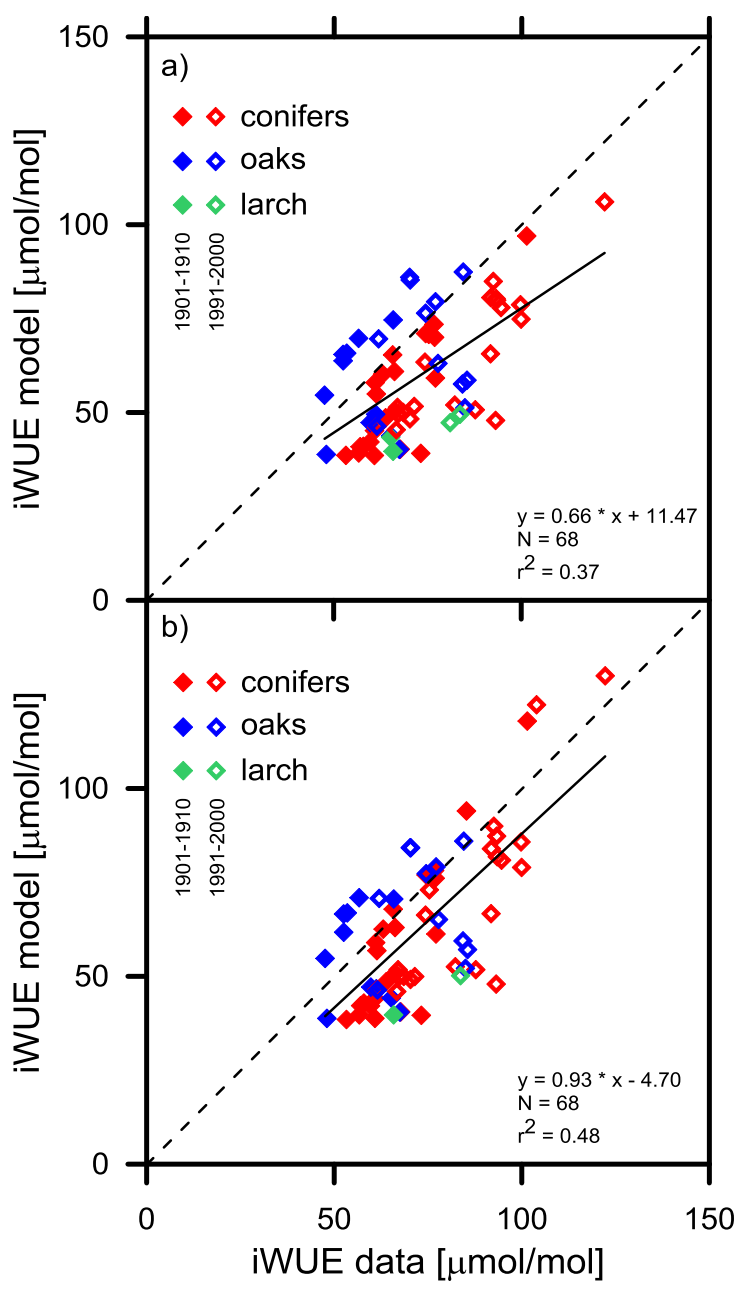


Figure 4

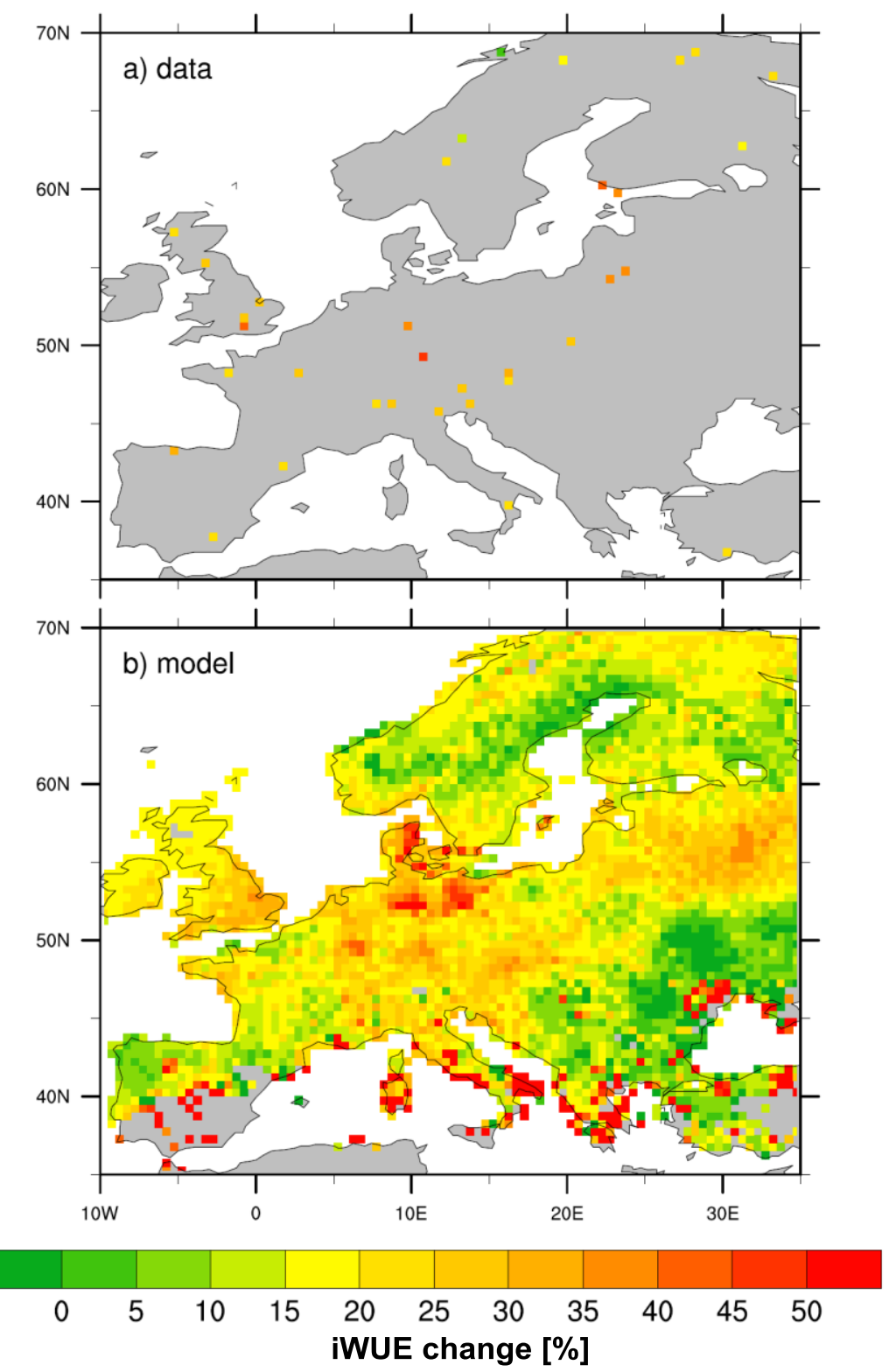


Figure 5
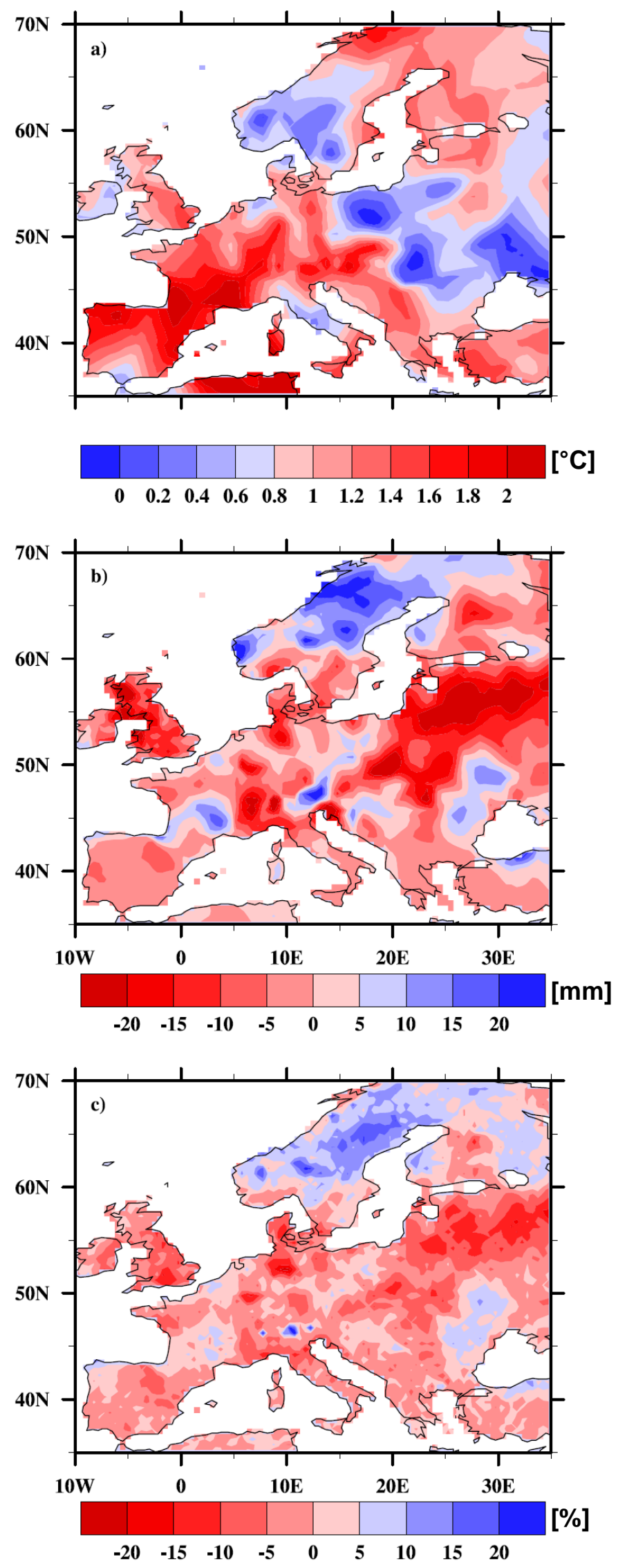
Figure 6

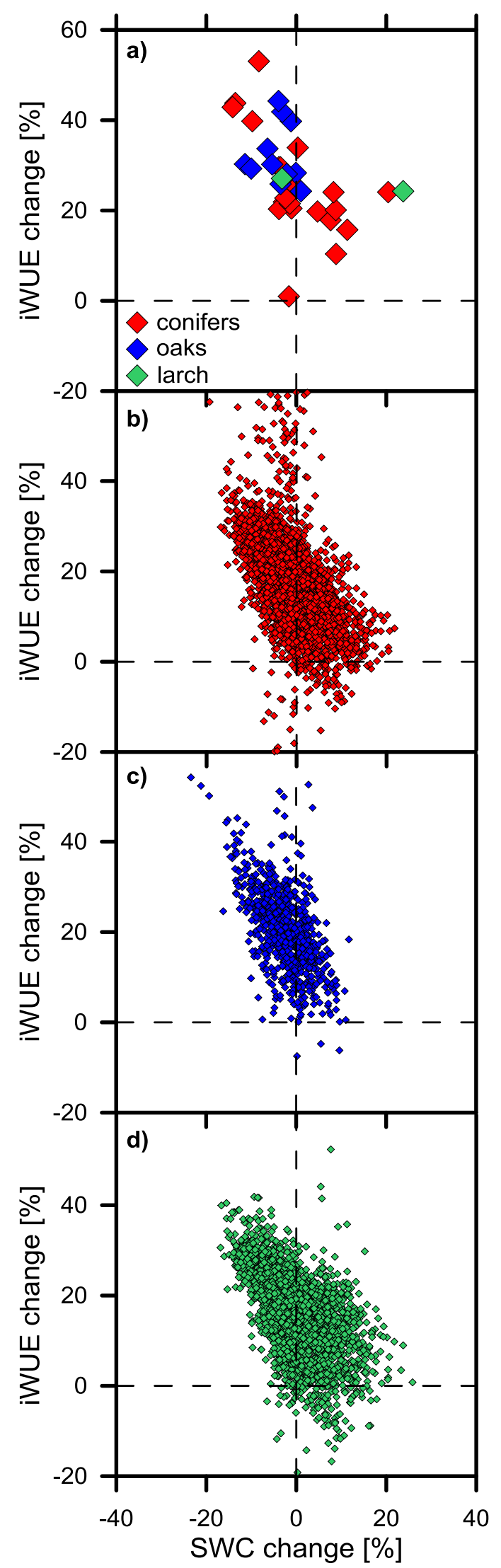

